\title{
Pale Damsel Bug Nabis capsiformis Germar (Insecta: Hemiptera: Nabidae) ${ }^{1}$
}

\author{
Karol L. Krey and Justin M. Renkema
}

\section{Introduction}

The pale damsel bug, Nabis capsiformis (Germar), one of the most widespread Nabis species, is a generalist predator that can be found in open areas, including coastal habitats (Lattin 1989). It is commonly reported throughout the southeastern United States, in a variety of ecosystems, it is particularly common in field and row crop agroecosystems. All nympal and adult life stages of Nabis capsiformis are excellent predators and can typically eat one lepidopteran egg or aphid per day when small and as many as two dozen eggs or other prey as later instars and adults. They can survive for up to two weeks without food and become cannibalistic if other prey are unavailable. They use their thickened raptorial front legs that are lined with spines to catch and hold prey, then suck out the body contents with their piercing mouthparts.

Damsel bugs, including the pale damsel bug, are so named because of the way they hold their front legs up, as though they were lifting a skirt hem to curtsey. At first glance, they appear like a cross between a mantis and an assassin bug.

\section{Distribution}

Nabis capsiformis is a cosmopolitan species occurring in the US from North Carolina to Texas and Florida, and southward into Central America (Harris 1928; Harris 1931; Kerzhner 1983; Pericart 1987; Stehlik 1970). Additional reports have found Nabis capsiformis with a range throughout South America, Russia, Africa, and Europe (Kerzhner and Henry 2008; Scharff 1912). In a study by Kerzhner (1983), it was reported as the only nabid species recovered from aerial insect samples taken over the Atlantic, Indian, and Pacific Oceans.

\section{Description}

Adult Nabis capsiformis are generally pale to light brown. Their bodies are elongated and covered with fine white hairs. The head is narrow and covered sparsely with whitish hairs, which are more abundant ventrally (Figure 1). They have a brown area between the eyes and antennae that run laterally (Figure 1, Cornelis et al. 2012). Antennae are long and slender with small hairs. The mouthparts are long, needle-like, and tucked under the head and body at rest, but are flexible and can be positioned in front of the head when feeding (Figures 2 and 3D). The pronotum is covered with long soft hairs with a brown stripe in the middle (in some specimens this stripe is diffused). The anterior lobe is shaded brown and the posterior lobe has a suture (Latin for "a seam"; exist at the junctions between plates of hardened cuticle of exoskeleton) and a roughened surface. The scutellum is brown in the center with two depressions, and the sides are clear. The ventral sides of the abdomen both have a brown stripe (Figure 2). Nabis capsiformis adults only occur in the macropterous (having large and long

1. This document is EENY-703, one of a series of the Department of Entomology and Nematology, UF/IFAS Extension. Original publication date April 2018. Visit the EDIS website at http://edis.ifas.ufl.edu. This document is also available on the Featured Creatures website at http://entnemdept.ifas.ufl. edu/creatures/.

2. Karol L. Krey; and Justin M. Renkema; Department of Entomology and Nematology, UF/IFAS Gulf Coast Research and Education Center, Wimauma, FL 33598.

The Institute of Food and Agricultural Sciences (IFAS) is an Equal Opportunity Institution authorized to provide research, educational information and other services only to individuals and institutions that function with non-discrimination with respect to race, creed, color, religion, age, disability, sex, sexual orientation, marital status, national origin, political opinions or affiliations. For more information on obtaining other UF/IFAS Extension publications, contact your county's UF/IFAS Extension office. 
wings) state (Pericart 1987). The legs are long and slender, with long white hairs.

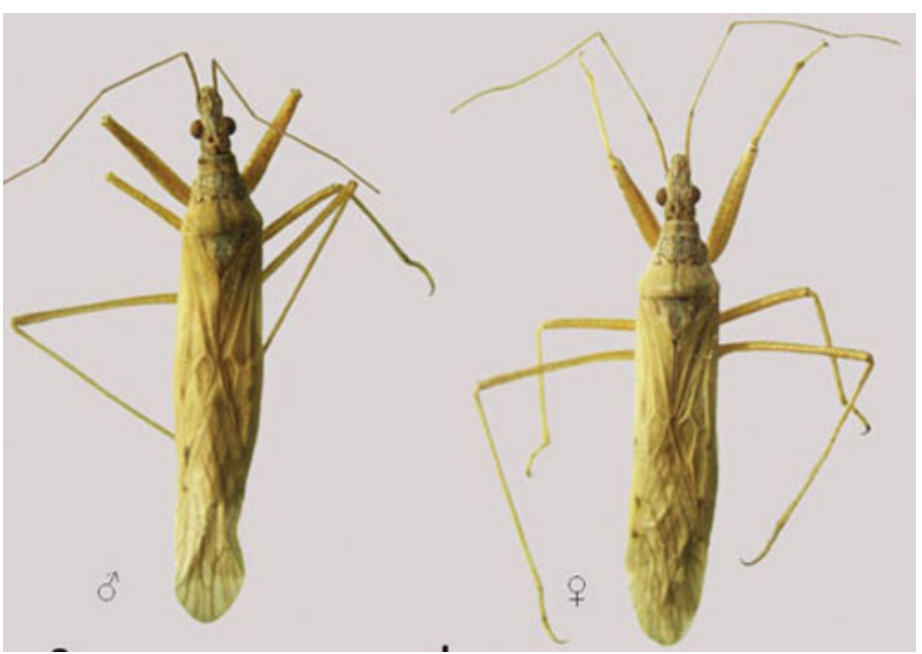

Figure 1. Nabis capsiformis (Germar) dorsal view of adult male and female specimens.

Credits: @ Marcela Cornelis, María C. Coscarón

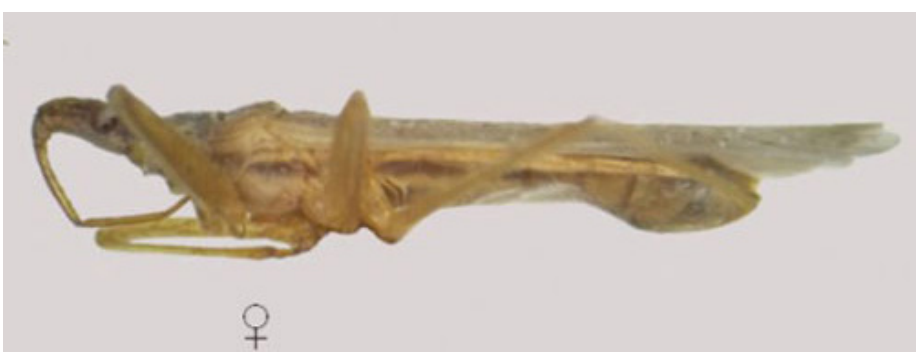

Figure 2. Lateral view of adult female Nabis capsiformis (Germar). Credits: @ Marcela Cornelis, María C. Coscarón

\section{Host Plants}

Damsel bugs are commonly found on many plants, including field crops such as alfalfa, cotton, and soybean, as well as in orchards (Braman and Yeargan 1990; Dinkins et al. 1970; Miliczky and Horton 2005). Krey et al. (2017) found high populations of Nabis in commercial potato fields in Washington. Nabis capsiformis have recently been found in organic strawberry fields of central Florida (K. Krey unpublished).

\section{Life Cycle}

Damsel bugs undergo simple metamorphosis, passing through an egg and five nymphal stages before adulthood.

\section{Eggs}

During warm months, Nabis capsiformis adult females can lay up to 200 eggs that are inserted into the stems of low-growing plants. The egg is elongated and oval shaped, narrow at the base and progressively widening towards the apex (Ojeda-Peña 1971). The eggs are white when recently oviposited, turning yellow as they develop. Before the egg hatches, two black spots appear. These are the developing eyes of the nymph (Ojeda-Peña 1971). The incubation period is about eight days in summer and 12 days in winter (Ojeda-Peña 1971).

\section{Nymphs}

Damsel bug nymphs develop over three to four weeks, depending on temperature. They are active shortly after hatching and begin feeding immediately. The nymphs look like small, wingless versions of the adults (Figure 3 ). Male Nabis capsiformis nymphs develop faster than females, averaging 18 days compared to 22.4 days at $26^{\circ} \mathrm{C}-28^{\circ} \mathrm{C}$ (Hormchan et al. 1976).

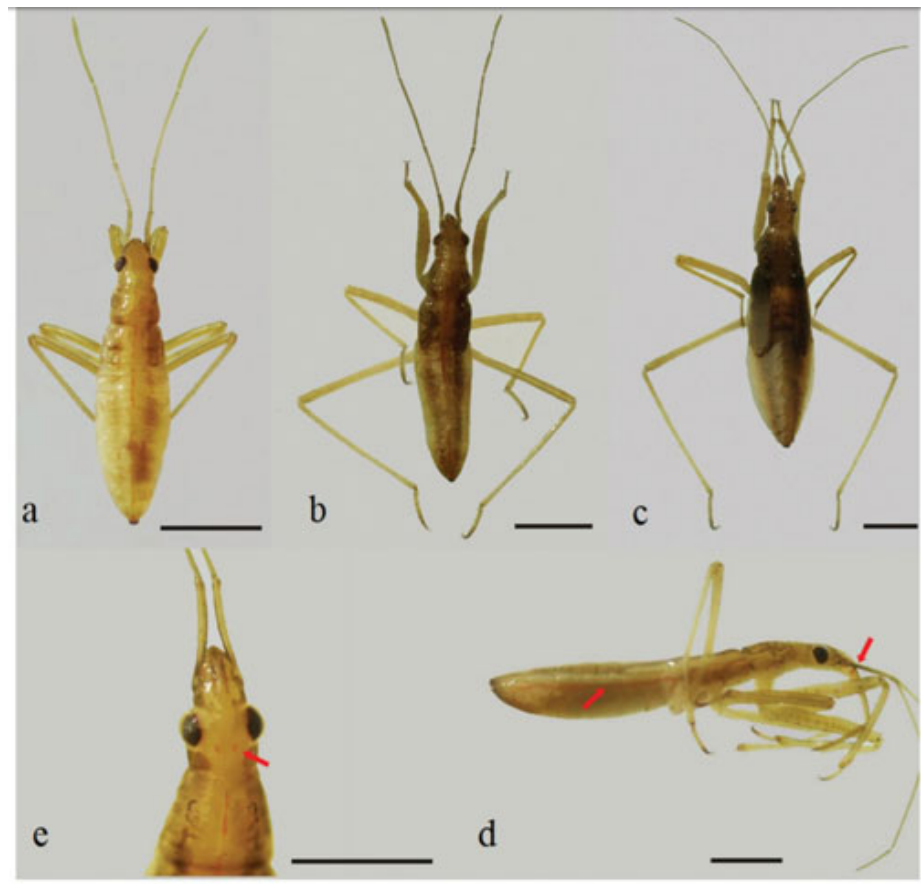

Figure 3. Nabis capsiformis (Germar), a) third instar dorsal view; b) fourth instar dorsal view; c) fifth instar dorsal view; d) abdomen with a red stripe lateral, and e) head with two red dots in the post-ocular region. Scale line: $1 \mathrm{~mm}$.

Credits: ๑ Marcela Cornelis, María C. Coscarón

\section{Adults}

The adults have a multivoltine (multiple generations per year) life history (Guppy 1986; Harris 1928) and most overwinter as adults or late-instars in weeds, ground cover, or winter crops, such as corn and potato in Florida. Adults can live 14.9 (males) and 21.6 (females) days under laboratory conditions $\left(26^{\circ} \mathrm{C}-28^{\circ} \mathrm{C}, 60 \%-70 \% \mathrm{RH}\right.$, and 15:9 L:D photoperiod), with total generation time around 51.6 days (Hormchan et al. 1976). Longevity of adult Nabis spp. has been reported to be almost 60 days (Rebolledo et al. 2005). 


\section{Importance}

Members of the genus Nabis are some of the most common predators found in association with row crops in the southeastern United States (Deitz et al. 1976; Dinkins et al. 1970; Pitre et al. 1978; Shepard et al. 1974). All damsel bug species are predaceous, attacking many small insects and other arthropod species (Lattin 1989) that are found in crops and gardens. Nabis capsiformis is a predator of aphids, moth eggs, and small caterpillars, including corn earworm (Helicoverpa zea), imported cabbageworm (Pieris rapae), and some armyworm species (Ashby 1974, Buschman et al. 1977, Godfrey et al. 1989). Other prey may include mites, thrips, leafhoppers, tarnished plant bug nymphs, asparagus beetle (Crioceris asparagi), and Colorado potato beetle (Leptinotarsa decemlineata) eggs and larvae (Jessep 1964; Samson and Blood 1980).

Nabis capsiformis can be found in grassy fields or home gardens, where they shelter in low growing grasses and ground covers such as herbaceous vegetation and shrubs. Maintaining such plant environments will encourage populations of Nabis capsiformis and increase the level of pest predation they provide. Nabis capsiformis are not currently commercially available for release against pests.

\section{Selected References}

Ashby JW. 1974. "A study of arthropod predation of Pieris rapae L. using serological and exclusion techniques." Journal of Applied Ecology 11: 419-425.

Braman SK, Yeargan KV. 1990. "Phenology and abundance of Nabis americoferus, $N$. roseipennis, and N. rufusculus (Hemiptera: Nabidae) and their parasitoids in alfalfa and soybean." Journal of Economic Entomology 83: 823-830.

Buschman LL, Whitcomb WH, Hemenway RC, Mays DL, Ru N, Leppla NC, Smittle BJ. 1977. "Predators of velvetbean caterpillar eggs in Florida soybeans." Environmental Entomology 6: 403-407.

Cornelis M, Quirán E, Coscarón MC. 2012. "Description of some immature stages of Nabis (Tropiconabis) capsiformis (Hemiptera: Nabidae)." Revista Mexicana de Biodiversidad 83: 1009-1012.

Deitz LL, Van Duyn JW, Bradley Jr JR, Rabb RL, Brooks WM, Stinner RE. 1976. "A guide to the identification and biology of soybean arthropods in North Carolina." North Carolina Agricultural Experiment Station Technical Bulletin 238: 1-264.
Dinkins RL, Brazzel JR, Wilson CA. 1970. "Seasonal incidence of major predaceous arthropods in Mississippi cotton fields." Journal of Economic Entomology 63: 814-817.

Godfrey KE, Whitcomb WH, Stimac JL. 1989. “Arthropod predators of velvetbean caterpillar, Anticarsia gemmatalis Hübner (Lepidoptera: Noctuidae), eggs and larvae." Environmental Entomology 18: 118-123.

Guppy JC. 1986. "Bionomics of the damsel bug, Nabis americoferus Carayon (Hemiptera: Nabidae), a predator of the alfalfa blotch leafminer (Diptera: Agromyzidae)." The Canadian Entomologist 118: 745-751.

Harris HM. 1931. "Nabidae from the State of Parana." Annales Musei Zoologici Polonici 9: 179-185.

Hormchan P, Schuster MF, Hepner LW. 1976. "Biology of Tropiconabis capsiformis." Annals of the Entomological Society of America 69: 1016-1018.

Jessep CT. 1964. "A note on the feeding habits of Nabis capsiformis Germar." New Zealand Entomologist 3: 23.

Kerzhner IM. 1983. "Airborne Nabis capsiformis (Heteroptera: Nabidae) from the Atlantic, Indian and Pacific Oceans." International Journal of Entomology 25: 273-275.

Kerzhner IM, Henry TJ. 2008. “Three new species, notes and new records of poorly known species, and an updated checklist for the North American Nabidae (Hemiptera: Heteroptera)." Proceedings of the Entomological Society of Washington 110: 988-1011.

Krey KL, Blubaugh CK, Chapman EG, Lynch CA, Snyder GB, Jensen AS, Fu Z, Prischmann-Voldseth DA, Harwood JD, Snyder WE. 2017. "Generalist predators consume spider mites despite the presence of alternative prey." Biological Control 115: 157-164.

Lattin JD. 1989. "Bionomics of the Nabidae." Annual Review of Entomology 34: 383-400.

Miliczky ER, Horton DR. 2005. "Densities of beneficial arthropods within pear and apple orchards affected by distance from adjacent native habitat and association of natural enemies with extra-orchard host plants." Biological Control 33: 249-259.

Ojeda-Peña D. 1971. "Biologia y hábitos de Nabis capsiformis Germar (Hemip.: Nabidae)." Sociedad Entomológica de Perú 14: 297-303. 
Pericart J. 1987. "Hémiptères Nabidae d'Europe occidentale et du Maghreb." Faune of France 71: 1-169.

Pitre HN, Hillhouse TL, Donahoe MC, Kinard HC. 1978. Beneficial arthropods on soybeans and cotton in different ecosystems in Mississippi. Mississippi Agricultural \& Forestry Experiment Station 90: 1-9.

Rebolledo R, Villegas G, Klein C, Aguilera A. 2005. “Fluctuación poblacional, capacidad depredadora y longevidad de Nabis punctipennis Blanchard (Hemiptera: Nabidae)." Agricultura Técnica (Chile) 65: 442-446.

Samson PR, Blood PRB. 1980. "Voracity and searching ability of Chrysopa signata (Neuroptera: Chrysopidae), Micromus tasmaniae (Neuroptera: Hemerobiidae), and Tropiconabis capsiformis (Hemiptera: Nabidae)." Australian Journal of Zoology 28: 575-580.

Scharff RF. 1912. Distribution and origin of life in America. New York, NY: Macmillan. 497 pp.

Shepard M, Carner GR, Turnipseed SG. 1974. "Seasonal abundance of predaceous arthropods in soybeans." Environmental Entomology 3: 985-988.

Stehlik J. 1970. "Contribution to the knowledge of Heteroptera of Moravia and Slovakia." Acta Musei Moraviae 55: 209-232. 